\title{
Xao Tam Phan (Paramignya trimera) methanol extract induced apoptosis in hepatocellular carcinoma HepG2 cell line in vitro
}

\author{
Sinh Truong Nguyen ${ }^{1,2,3}$, Nghia Minh Do ${ }^{1,2,3}$, Phuc Vo Hong ${ }^{1,2,3}$, Trinh Thi - Tu Nguyen ${ }^{1,3}$, Kiet Dinh Truong ${ }^{4}$, \\ Phuc Van Pham $1,2,3,5, *$ (i)
}

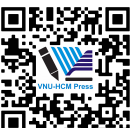

Use your smartphone to scan this QR code and download this article

${ }^{1}$ Stem Cell Institute, University of Science Ho Chi Minh City, Viet Nam

${ }^{2}$ Cancer Research Laboratory, University of Science Ho Chi Minh City, Viet Nam

${ }^{3}$ Viet Nam National University Ho Chi Minh City, Viet Nam

${ }^{4}$ Medical Genetic Institute, Ho Chi Minh City, Viet Nam

${ }^{5}$ Laboratory of Stem Cell Research and Application, University of Science Ho Chi Minh City, Viet Nam

\section{Correspondence}

Phuc Van Pham, Stem Cell Institute University of Science Ho Chi Minh City, Viet Nam

Cancer Research Laboratory, University of Science Ho Chi Minh City, Viet Nam

Viet Nam National University Ho Chi Minh City, Viet Nam

Laboratory of Stem Cell Research and Application, University of Science Ho Chi Minh City, Viet Nam

Email: pvphuc@hcmuns.edu.vn; phucpham@sci.edu.vn

History

- Received: 15 Dec 2019

- Accepted: 03 Mar 2020

- Published: 31 Mar 2020

DOI : 10.32508/stdj.v23i1.2013

\section{Check for updates}

\section{Copyright}

( ) VNU-HCM Press. This is an openaccess article distributed under the terms of the Creative Commons Attribution 4.0 International license.

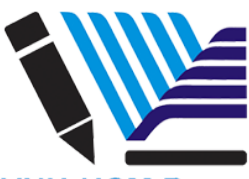

VNU-HCM Press

\begin{abstract}
Introduction: Xao Tam Phan (Paramignya trimera) has long been used in Viet Nam as an herbal medicine for the treatment of Hepatitis, hepatocellular carcinoma, and diabetes. This study aimed to determine the anti-proliferation effect of Paramignya trimera extract (P. trimera extract) on HepG2 hepatocellular carcinoma cells. Methods: AlamarBlue assay was used to determine the $I C_{50}$ values of P. trimera extract on HepG2 cells. Adipose-derived stem cells (ADSCs) was used as normal cell control. For apoptosis examination, P. trimera extract-treated HepG2 cells were incubated with Annexin V/Propidium iodide (PI). Then they have been analyzed their expression of Annexin- $\mathrm{V}$ and PI by flow cytometry. The cell nuclear degradation also was evaluated by PI/Hoechst 33342 staining assay. Results: Doxorubicin and P. trimera extract $I C_{50}$ values on HepG2 cells were $55.13 \pm$ $2.028 \mathrm{ng} / \mathrm{ml}$ and $582.533 \pm 16.521 \mu \mathrm{g} / \mathrm{ml}$, respectively. Those on ADSCs were $5.96 \pm 0.56 \mathrm{ng} / \mathrm{ml}$ and $268.976 \pm 19.325 \mu \mathrm{g} / \mathrm{ml}$, respectively. Side effect index value (SEI) of $P$. trimera extract was $2.175 \pm 0.12$, and the SEl of doxorubicin was $8.71 \pm 0.36$. Flow cytometry analysis indicated significant apoptosis on P. trimera extract-treated HepG2 cells at a dose of $500 \mu \mathrm{g} / \mathrm{ml}(32.39 \pm 2.28 \%$ apoptotic cells, and $14.63 \pm 1.59 \%$ necrotic cells). Nuclear aggregation and degradation was seen on $500 \mu \mathrm{g} / \mathrm{ml}$ P. trimera treated HepG2 cells. Conclusion: P. trimera extract could inhibit HepG2 hepatocellular carcinoma cell proliferation by inducing apoptosis.
\end{abstract}

Key words: Paramignya trimera, HepG2, side index effect, apoptosis, flow cytometry

\section{INTRODUCTION}

According to Globcan 2018 statistics, 841.080 people were diagnosed with liver cancer worldwide; an estimated 781,631 people died from the disease ${ }^{1}$. Among the most common types of fatal cancer in the world, liver cancer has the fourth highest mortality rate and accounts for the second-highest death rate for men ${ }^{2}$. Among the regions, Asia is the most alarming region. Asia has consistently led the way in terms of new cases of diagnosis and mortality, as well as the proportion of people living with liver cancer. The highest is in West Asia and then Southeast Asia ${ }^{1}$.

According to IARC data in 2018, Viet Nam had 25335 new cases, 25404 deaths, and 21055 people living for five years with liver cancer ${ }^{3}$. Liver cancer accounts for the highest percentage of all common diseases, as well as the leading cause of death in Viet Nam. There have been many developed methods to treat cancer. Among them, five routine methods are commonly used: tumor removal surgery, chemotherapy, radiation therapy, hormone therapy, and immunotherapy $^{4}$. Depending on the type of cancer, the patient's condition that the doctor chooses a suitable treatment or a combination of treatments to bring the best effect.
In particular, chemotherapy is still an important method to treat this disease. However, the cases of drug resistance are getting a problem. Besides, chemotherapy also causes many side effects, the possibility of cancer recurrence. Research on developing new drugs is still being promoted, including the use of compounds derived from nature, especially medicinal plants from ancient times. Up to date, folk remedies still play an essential role in the treatment and protection of human health. Vinca alkaloid, saponins, flavonoids, and their derivatives are anti-cancer compounds isolated from plants and scientifically proven to treat cancer ${ }^{5-7}$.

Vietnam is located in the tropics, with abundant biological resources, including many herbs that, according to folk medicine points, can cure cancer. However, most are used according to folk experience or used as a functional food, without precise mechanism. In Vietnam and Thailand, P. trimera extract is considered a folk medicine to treat hepatitis, liver cancer, and diabetes ${ }^{8}$. However, studies on P. trimera in general and their medicinal properties are quite limited. Xao Tam Phan is a small tree with a climbing body; body more than $4 \mathrm{~m}$ long, about $10 \mathrm{~cm}$ diameter; 
body and branches hairless, spiky, and to 7 to $8 \mathrm{~cm}$ long, slightly curved down. Leaves grow in a cluster or three-fold pattern; thick slab; oblong to extended narrow circles; size $10-18$ x $1-2.5 \mathrm{~cm}$; The whole cover is slightly bent; tendon filler $8-10$ pairs; petioles short, 2 - $3 \mathrm{~mm}$ long. The parts of the plant have the essential oils, and their roots are at most ${ }^{8}$. In Vietnam, the $P$. trimera tree grows mainly in tropical forests, especially in the central provinces such as Khanh Hoa, Ninh Thuan, and Binh Thuan, in addition to areas adjacent to Laos and Cambodia.

According to folk experience, $P$. trimera roots are used as medicine. P. trimera root has a slightly bitter taste, slightly acrid, slightly sweet. According to some analyzes, $P$. trimera extract contains saponin $(267.15 \mathrm{mg}$ $\mathrm{EE} / \mathrm{g}$ dry sample), proanthocyanidin (3.98 mg CE/g dry sample), phenolic (11.27 mg GAE/g dry sample), flavonoid (19.88 mg RE/g dry sample) ${ }^{9}$. Besides, $P$. trimera extract has also been shown to contain coumarins with potent anti-inflammatory properties, including ostruthin and ninhvanin ${ }^{10}$. Moreover, there are also studies proving $P$. trimera has many antioxidants. In another recent study, it was shown that $P$. trimera extract has a strong ability to inhibit MCF-7 breast cancer cells in both $2 \mathrm{D}$ and $3 \mathrm{D}$ culture conditions ${ }^{11}$.

However, there have not been many studies on the anti-proliferation of this plant on HepG2 hepatocellular carcinoma cells. Therefore, this study aimed to assess the effects of $P$. trimera extract on HepG2 hepatocellular carcinoma cells.

\section{MATERIAL — METHODS}

\section{Cell culture}

HepG2 hepatocellular carcinoma cells were obtained from ATCC (Manassas, VA). They were cultured in DMEM/F12 medium (Thermo Fisher Scientific, Waltham, MA) containing $10 \%$ fetal bovine serum (FBS) and 1\% antibiotic-mycotic (Gibco, Thermo Fisher Scientific, MA). HepG2 cells were cultured at $5 \% \mathrm{CO}_{2}$ humidified atmosphere at $37^{\circ} \mathrm{C}$. Cells were passed at $80 \%$ confluency by trypsin/EDTA $(0.025 \%)$ (Gibco, Thermo Fisher Scientific, MA).

Adipose-derived stem cells (ADSCs) were isolated from adipose tissues with consent from the donor as the published protocol ${ }^{12}$. Adipose tissues were kept in cool temperature in PBS solution containing $1 \%$ antibiotic-antimycotic solution, and transferred to the laboratory for subsequent processing. The stromal vascular fraction (SVF) was extracted from the adipose tissue by the Cell Extraction Kit (Regenmedlab, Ho Chi Minh City, VN). Then SVF was cultured to collect ADSCs per a previously published protocol. All assays were performed per the published study ${ }^{12}$.

\section{Cytotoxicity assay}

HepG2 and ADSC cells were seeded in 96 wells plate. The cell density was 2500 cells per well. After $24 \mathrm{~h}$, cells were treated with P. trimera extract at concentration 2000, 1000, 500, 250, 125, 60,30,15,7 $\mu \mathrm{g} / \mathrm{ml}$. Parallelly, HepG2 cells also treated with doxorubicin at concentrations of 2000, 1000, 500, 250, 125, 60, 30, $15,7 \mathrm{ng} / \mathrm{ml}$. After $48 \mathrm{~h}$ incubation, cells were evaluated viability by Alamar Blue assay.

Side Effect Index (SEI) is calculated using the formula: $\mathrm{SEI}_{\text {P. trimera }}=\frac{\text { IC50 of P.trimera extract on HepG2 cells }}{\text { IC50 of P.trimera extract on ADSCS }}$

$\mathrm{SEI}_{\text {Doxorubicin }}=\frac{\text { IC50 of Doxorubicin HepG } 2 \text { cells }}{\text { IC50 of Doxorubin on ADSCs }}$

\section{Apoptosis assay}

HepG2 cells were seeded in 6 wells plate. The cell density was 200.000 cells per well. Cells were treated with P. trimera extract at concentrations of $60,125,250$, 500 , and $1000 \mu \mathrm{g} / \mathrm{ml}$ and incubated in $48 \mathrm{~h}$. Cells were labeled with $3 \mu \mathrm{L}$ Annexin V-FITC (BD Biosciences, Franklin Lakes, NJ) (and $3 \mu \mathrm{l}$ of Propodium Iodide (PI) in $500 \mu \mathrm{l}$ of binding buffer for 15 mins to detect apoptotic and necrotic cell death using a FACSCalibur Flow Cytometer. Data were analyzed by Cellquest software (BD Biosciences).

\section{Nuclei staining assay}

HepG2 cells were added into a 6-well plate with a density of 200000 cells/well. HepG2 cells were treated with $P$. trimera extract at concentrations of 2000 $\mu \mathrm{g} / \mathrm{ml}, 500 \mu \mathrm{g} / \mathrm{ml}, 125 \mu \mathrm{g} / \mathrm{ml}$, and control for 48 hours. Similarly, doxorubicin was added at concentrations of $300 \mathrm{ng} / \mathrm{ml}, 60 \mathrm{ng} / \mathrm{ml}, 15 \mathrm{ng} / \mathrm{ml}$, and control for 48 hours. Then, cells mixed with $50 \mathrm{ml}$ Hoechst 33342 and $10 \mathrm{ml}$ Propidium Iodide, incubated for 10 minutes. Finally, the cell suspension was dropped in the lame, observed under the microscope fluorescence objective 40X (Carl-Zeiss, Germany).

\section{RESULTS}

\section{Cytotoxicity of $\boldsymbol{P}$. trimera extract and dox- orubicin on HepG2 cells}

The results showed that $\mathrm{IC}_{50}$ values of $P$. trimera extract on ADSCs and HepG2 cells were $268.98 \pm$ $19.33 \mu \mathrm{g} / \mathrm{ml}$ and $582.53 \pm 16.52 \mu \mathrm{g} / \mathrm{ml}$, respectively (Figure 1). The $\mathrm{IC}_{50}$ values of doxorubicin on ADSCs and HepG2 cells are $5.96 \pm 0.56 \mathrm{ng} / \mathrm{ml}$ and $55.13 \pm$ $2.028 \mathrm{ng} / \mathrm{ml}$, respectively. We performed the side effects index (SEI) of $P$. trimera and doxorubicin. SEI is considered as a method to assess the toxicity of a substance on a normal cell line. The result showed that SEI value of $P$. trimera was $2.175 \pm 0.12$, and SEI value of doxorubicin was $8.71 \pm 0.36$. 
A

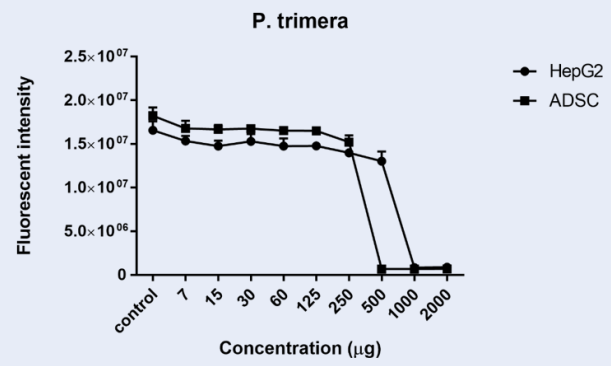

C

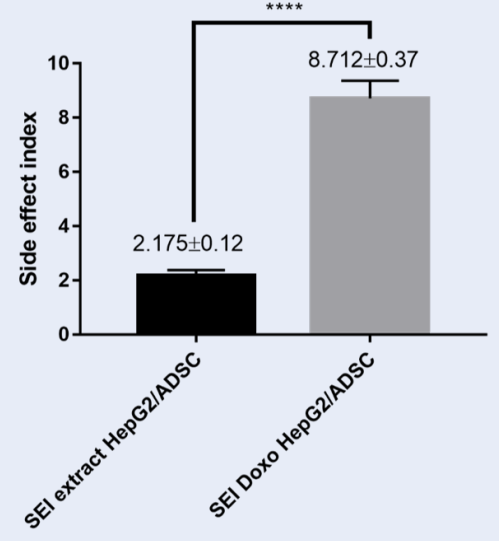

B

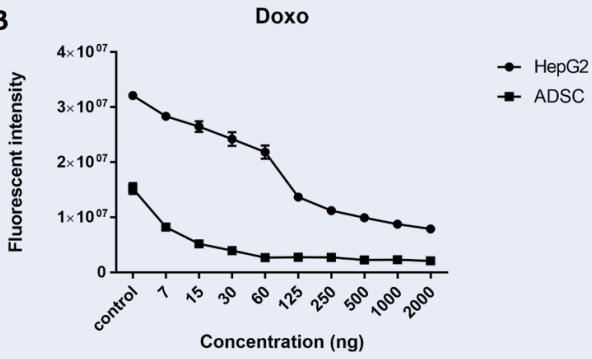

Figure 1: Anti-proliferation of $\boldsymbol{P}$. trimera extract and doxorubicin on HepG2 cells and ADSCs. Cells were seeded into 96-well plates for 24 hours. Cells were then treated with P. trimera extract at concentrations 2000, $1000,500,250,125,60,30,15,7 \mu \mathrm{g} / \mathrm{ml}$. Parallelly, cells also treated with doxorubicin at the concentration 2000 , $1000,500,250,125,60,30,15,7 \mathrm{ng} / \mathrm{ml}$. After 48 hours, cell viability was measured with dye Alamar Blue assay. A. Cell proliferation curve of HepG2 cells and ADSCs when treated with $P$. trimera extract. B. Cell proliferation curve of HepG2 cells and ADSCs when treated with doxorubicin. C. Comparison of SEls between P. trimera extract and Doxorubicin on HepG2 cells and ADSCs. ${ }^{* * * *} \mathrm{P}<0.0001$. The experiment was triplicated.

\section{Apoptosis of HepG2 cells after treatment of P. trimera extract}

Results showed that the total percentage of late apoptosis increased in dose-dependent manner. Late apoptosis population at concentrations of $P$. trimera extract $60,125,250,500,1000 \mu \mathrm{g} / \mathrm{ml}$ increased by $6.687 \pm 0.78 \%, 7.28 \pm 0.85 \%, 9.77 \pm 1.35 \%, 7.743$ $\pm 2.67 \%, 32.82 \pm 2.28 \%, 49.28 \pm 2.43 \%$ respectively (Figure 2). At the concentration of $500 \mu \mathrm{g} / \mathrm{ml}$, the total cell death counted almost $50 \%$. When the concentration increased up to $1000 \mu \mathrm{g} / \mathrm{ml}$, cell death was at $80 \%$. This result proves that $P$. trimera extract can induce apoptosis in HepG2 cells.

\section{Cell nuclei fragmentation of HepG2 cells af- ter treatment of $P$. trimera and doxorubicin extracts}

PI and Hoechst 33342 staining results showed in both $P$. trimera extract treatment group, and doxorubicin treatment group, the number of dead cells increased in the manner of concentration dependence. These cells have DNA compressed or fragmented. In control, cells were mainly in blue fluorescent with contact cell nuclei. When cells were treated with $P$. trimera extract at the concentration of $\mathrm{IC}_{50}$ value and at $1 / 4$ of $\mathrm{IC}_{50}$ value, dead cells were significantly increased compared to that in control $(582.533 \pm 16.521 \mu \mathrm{g} / \mathrm{ml})$ at $\mathrm{IC}_{50}$, and $49.33 \pm 2.50 \%$ at $\frac{1}{4}$ of $\mathrm{IC}_{50}$ compared to $7.00 \pm 1.00 \%$ at control). Particularly, when cells were treated with $P$. trimera extract at $4 \times \mathrm{IC}_{50}$ concentration, most cells were no longer intact $(94.00 \pm$ $6.25 \%$ ), stained with red fluorescent (Figure 3). This result proves that $P$. trimera extract can cause HepG2 cell death and nuclear fragmentation.

\section{DISCUSSION}

According to the World Cancer Research Organization (IARC), Vietnam is in an epidemiological area with a high rate of liver cancer. In 2018, liver cancer led to the number of new cases and deaths in the country. Studies looking for extracts or compounds to 


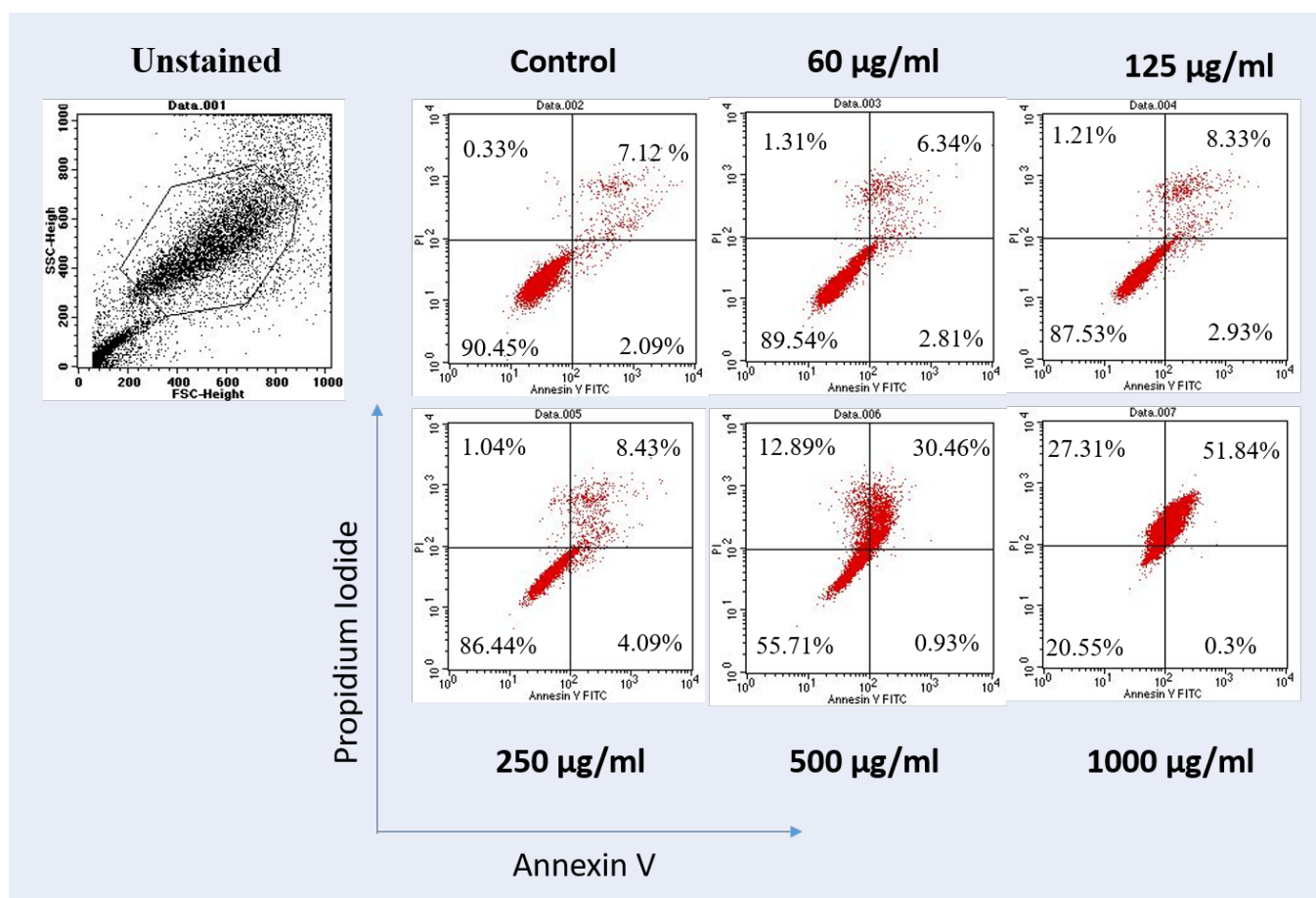

Figure 2: Apoptosis population of HepG2 after treatment with $\boldsymbol{P}$. trimera extract. HepG2 cells were treated with P. trimera extract at concentrations of $60,125,250,500$ and $1000 \mu \mathrm{g} / \mathrm{ml}$. After 48 hours, cells were stained with Annexin $\mathrm{V}$ and $\mathrm{PI}$ and analyzed with FACSCalibur flow cytomtter.

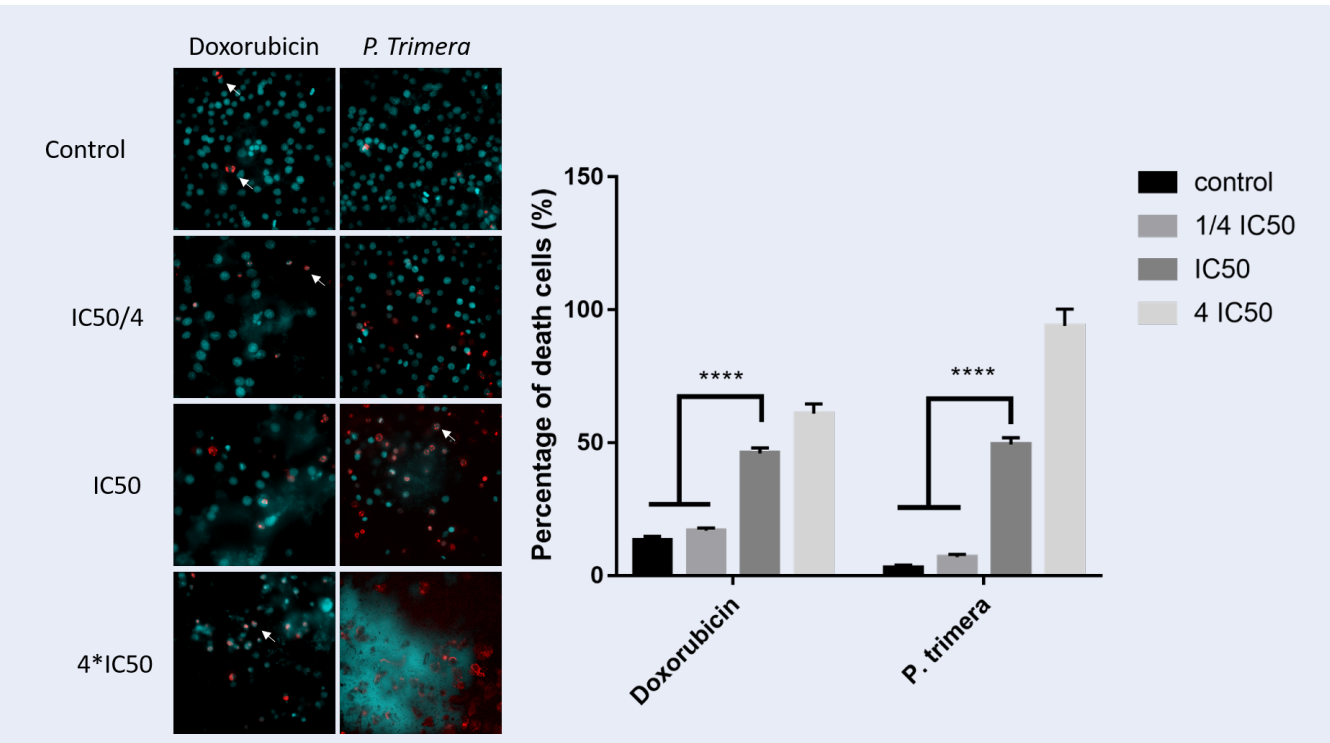

Figure 3: DNA fragmentation of HepG2 cells (magnification at X40). HepG2 cells were treated with $P$. trimera extract at concentrations of $4 \times \mathrm{IC}_{50}(2000 \mu \mathrm{g} / \mathrm{ml}), \mathrm{IC}_{50}(500 \mu \mathrm{g} / \mathrm{ml}), \frac{1}{4} \mathrm{IC} 50(125 \mu \mathrm{g} / \mathrm{ml})$, and control. Similarly, doxorubicin was treated at concentrations of $4 \times \mathrm{IC}_{50}(300 \mathrm{ng} / \mathrm{ml}), \mathrm{IC} \mathrm{C}_{50}(60 \mathrm{ng} / \mathrm{ml}), \frac{1}{4} \mathrm{IC} \mathrm{C}_{50}(15 \mathrm{ng} / \mathrm{ml})$, and control. After 48 hours of treatment, cells were stained with Hoechst 33342 and PI dyes. Cells were then observed under ImageXpress Micro Confocal microscope. Cells underwent apoptosis have a nucleus of DNA that compresses and fragments, indicated by white arrow. The red cells at doxorubicin $4 \times I_{50}(300 \mathrm{ng} / \mathrm{ml}) ; \mathrm{IC}_{50}(60 \mathrm{ng} / \mathrm{ml}) ; \frac{1}{4} \mathrm{IC} \mathrm{C}_{50}(15$ $\mathrm{ng} / \mathrm{ml})$; control is $61 \pm 3.6 \% ; 46 \pm 2 \% ; 17 \pm 1 \% ; 13.3 \pm 31.53 \%$. The red cells at $P$. trimera $\mathrm{IC}_{50}(2000 \mu \mathrm{g} / \mathrm{ml}) ; \mathrm{IC}_{50}$ $(500 \mu \mathrm{g} / \mathrm{ml}) ; \frac{1}{4} \mathrm{IC} 50(125 \mu \mathrm{g} / \mathrm{ml})$; control is $94 \pm 6.25 \% ; 49.33 \pm 2.52 \% ; 7 \pm 1 \% ; 3 \pm 1 \%$, respectively. 
treat the disease are always promoted ${ }^{13}$. About $80 \%$ of cancer medicines approved by the US Food and Drug Administration (FDA) are derived from natural compounds, mainly from medicinal plants ${ }^{14}$. The rich and diverse biological resource of Vietnam is an abundant source of medicinal materials. There are many types of plants used as medicines. However, there is no scientific evidence of a transparent effect. Among them, Xao tam phan (P. trimera) is a plant belonging to the Citrus family (Rutaceae). In our previous study, $P$. trimera extract showed a strong inhibitory effect on MCF-7 breast cancer cell lines in 2D culture conditions $(260.8 \pm 16.54 \mu \mathrm{g} / \mathrm{ml})$ and $3 \mathrm{D}$ (IC $50168.9 \pm 11.65 \mu \mathrm{g} / \mathrm{ml}$ ). It was shown that $P$. trimera has a full inhibitory effect on the invasion of MCF-7 cells ${ }^{14}$. To clarify the impact of $P$. trimera extract on liver carcinoma line, we conducted a test to determine the impact of this extract on HepG2 cells. The $\mathrm{IC}_{50}$ value of $P$. trimera extract was established on two lines of HepG2 cells and ADSCs, and doxorubicin used as a positive agent. The results showed that the average $\mathrm{IC}_{50}$ values of $P$. trimera and doxorubicin on HepG2 cells were $582.53 \pm 16.52 \mathrm{ng} / \mathrm{ml}$ and $55.13 \pm 2.03 \mathrm{ng} / \mathrm{ml}$. For ADSCs, P. trimera extract had an average IC $_{50}$ value of $268.98 \pm 19.33 \mu \mathrm{g} / \mathrm{ml}$. The $\mathrm{IC}_{50}$ value of doxorubicin on ADSCs was $5.96 \pm$ $0.56 \mathrm{ng} / \mathrm{ml}$. Besides, the side effects index SEI values of $P$. trimera and doxorubicin were $2.175 \pm 0.12$ and $8.71 \pm 0.36$. This result proves that in addition to the inhibitory effect on the MCF-7 cell line published in the previous study ${ }^{11}$, P. trimera extract also has antiproliferation effects on the HepG2 cells and P. trimera has less side effects than doxorubicin. This could be a promising potential for cancer treatment.

Doxorubicin is one of the most commonly used drugs in cancer chemotherapy. The study showed that doxorubicin was removed from the body by reducing two electrons by carbonyl reductase, which is most important in the liver ${ }^{15}$. Doxorubicin resistance is also due to over-expression of the adenosine triphosphate-binding cassette (ABC) family, typically ABCB1 (MDR1; MDR1) or ABCC1 (MDR1-related gene $1 ; \mathrm{MRP} 1)^{16,17}$. These may be the cause of higher IC50 in HepG2 than those in ADSC.

Apoptosis is an important process for getting rid of cells that lose function in the body. Cancer cells, though not functioning, still exist due to their ability to evade programmatic death. The anticancer drug, therefore, aims to resist cell division or kill cancer cells through apoptosis or necrosis ${ }^{18}$. Flow cytometry result showed that after treatment of $P$. trimera extract, apoptosis population cells increased by 6.687 $\pm 0.78 \%, 7.28 \pm 0.85 \%, 9.77 \pm 1.35 \%, 7.74 \pm 2.67 \%$, $32.82 \pm 2.28 \%, 49.28 \pm 2.43 \%$ correspond to concentrations of $60,125,250,500$ and $1000 \mu \mathrm{g} / \mathrm{ml}$. In which the concentration of $500 \mu \mathrm{g} / \mathrm{ml}$ showed a significant increase in cyclic cell death rate (31\%). This result showed that $P$. trimera can activate the programmed pathway of death. Nuclear fragmentation, an important feature of programmed cell death, is biological damage at the molecular biology level. Results showed that cells treated with $P$. trimera have nuclei compressed, divided into small pieces, the cell membrane remains intact. This result provides further evidence that $P$. trimera extract has the ability to inhibit HepG2 cells through the programmed cell death.

\section{CONCLUSION}

Cancer is the leading cause of death worldwide. Live cancer is high rate of death in Vietnam. Traditional medicine plays the critical role in drug development. Vietnam possesses tropical forest with resources of potential herbal medicine. P.trimera is popularly used in primarily treatment of some disease. In this study, $P$. trimera has shown that it can anti-proliferate HepG2 cells at $\mathrm{IC}_{50} 268.98 \pm 19.33 \mu \mathrm{g} / \mathrm{ml}$, while $P$. trimera has less side effect on ADSCs compared to doxorubicin. This implicated that P. trimera is the potential herbal in further investigation of drug development for cancer.

\section{ABBREVIATIONS}

ADSC: adipose-derived stem cell

P. trimera: Paramignya trimera

SEI: side effects index

\section{COMPETING INTERESTS}

All authors equally contributed in this work. All authors read and approved the final version of the manuscript for submission.

\section{AUTHORS' CONTRIBUTIONS}

The authors report no conflicts of interest in this work.

\section{ACKNOWLEDGMENTS}

This work was supported by the Vietnam National University, Ho Chi Minh City, Vietnam, under grant A2015-18-01. 


\section{REFERENCES}

1. 11 liver fact sheet [http://gco.iarc.fr/today/data/factsheets/ca ncers/11-Liver-fact-sheet.pdf].

2. Facts in pictures/Detail/Cancer [https://www.who.int/news-r oom/facts-in-pictures/detail/cancer].

3. 704 Vietnam fact sheet [http://gco.iarc.fr/today/data/factshe ets/populations/704-viet-nam-fact-sheets.pdf].

4. Sudhaka A. History of cancer, ancient and modern treatment methods. Journal of cancer science \& therapy. 2009;1(2):1. PMID: 20740081. Available from: https://doi.org/10.4172/ 1948-5956.100000e2.

5. Man S, Gao W, Zhang Y, L H, C L. Chemical study and medical application of saponins as anti-cancer agents. Fitoterapia. 2010;81(7):703-714. PMID: 20550961. Available from: https://doi.org/10.1016/j.fitote.2010.06.004.

6. Batra P, Sharma AK. Anti-cancer potential of flavonoids: recent trends and future perspectives. 3 Biotech. 2013;3(6):439 459. PMID: 28324424 . Available from: https://doi.org/10.1007/ s13205-013-0117-5.

7. Newman DJ, Cragg GM. Natural products as sources of new drugs from 1981 to 2014 . Journal of natural products. 2016;79(3):629-661. PMID: 26852623. Available from: https: //doi.org/10.1021/acs.jnatprod.5b01055.

8. Hộ PH: Cây cỏ Việt Nam, tập 1, 2, 3. Nxb trẻ, Thành phố Hồ Chí Minh 1999.

9. Nguyen $T$, Pham NMQ, Vuong $Q$, Bowyer $M$, van Altena I A, Scarlett C. Phytochemical retention and antioxidant capacity of Xao tam phan ( Paramignya trimera ) root as prepared by different drying methods. Drying Technology. 2015;34(3):324-334. Available from: https://doi.org/10.1080/ 07373937.2015.1053566.

10. HL TA, D-C K, W K, TM H, NX N, PH Y, et al. Antiinflammatory coumarins from Paramignya trimera. Pharm Biol. 2017;55(1):1195-1201. PMID: 28245363. Available from: https://doi.org/10.1080/13880209.2017.1296001.

11. Nguyen-Thi LH, Nguyen ST, Tran T, Phan-Lu CN, Van TT, Pham PV. Anti-cancer Effect of Xao Tam Phan Paramignya trimera
Methanol Root Extract on Human Breast Cancer Cell Line MCF7 in 3D Model. Advances in experimental medicine and biology . 2018;2018([First Online]). Available from: https://doi.org/ 10.1007/5584_2018_148.

12. P P, NB V, NL-C P, DM L, NC T, NH T, et al. Good manufacturing practice-compliant isolation and culture of human adipose derived stem cells. Biomedical Research and Therapy. 2014;4(1):1-9. Available from: https://doi.org/10.7603/s40730014-0021-6.

13. Saxena M, Saxena J, Nema R, Singh D, Gupta A. Phytochemistry of medicinal plants. Journal of pharmacognosy and phytochemistry. 2013;1(6).

14. DJ N, GM C. Natural products as sources of new drugs over the 30 years from 1981 to 2010 . Journal of natural products. 2012;75(3):311-335. PMID: 22316239. Available from: https: //doi.org/10.1021/np200906s.

15. $\mathrm{N} \mathrm{K}, \mathrm{K} \mathrm{H}, \mathrm{H}-\mathrm{J} \mathrm{M}, \mathrm{U}$ GA, A M, I M, et al. Carbonyl reductase 1 is a predominant doxorubicin reductase in the human liver. Drug Metabolism and Disposition. 2008;36(10):2113-2120. PMID: 18635746. Available from: https://doi.org/10.1124/dmd.108. 022251.

16. $G L, X C, Q W, Z X, W Z, L Y$. The roles of four multi-drug resistance proteins in hepatocellular carcinoma multidrug resistance. Journal of Huazhong University of Science and Technology;27(2):173-175. PMID: 17497289. Available from: https://doi.org/10.1007/s11596-007-0217-8.

17. J W, JYW C, CC F, CH T, KP F, M Y. Transcriptional analysis of doxorubicin-induced cytotoxicity and resistance in human hepatocellular carcinoma cell lines. Liver International. 2009;29(9):1338-1347. PMID: 19627484. Available from: https://doi.org/10.1111/j.1478-3231.2009.02081.x.

18. Mahassni SH, Al-Reemi RM. Apoptosis and necrosis of human breast cancer cells by an aqueous extract of garden cress (Lepidium sativum) seeds. Saudi journal of biological sciences. 2013;20(2):131-139. PMID: 23961228. Available from: https://doi.org/10.1016/j.sjbs.2012.12.002. 